\title{
PENDIDIKAN AKHLAK MASA PANDEMI COVID-19 TAHUN 2021 PERSPEKTIF IBNU MISKAWAIH (STUDI KASUS DI SMK NEGERI 1 PEDAN)
}

\author{
Diah Novita Fardani \\ Universitas Islam Negeri Raden Mas Said Surakarta \\ diahnovita.novy@gmail.com
}

\begin{abstract}
Abstrak
Karakter Islam menjadi perhatian utama para pemikir klasik Islam, atau para filosof Muslim era klasik, terutama Ibnu Miskawaih. Hal ini mengindikasikan bahwa masalah karakter menjadi bagian terpenting dalam proses pendidikan sejak dulu dan tampaknya trend pendidikan karakter kembali menjadi perhatian para pakar pendidikan bahwa pengembangan etika atau karakter tidak bisa dipisahkan dari upaya mencerdaskan kehidupan bangsa. Konsep pendidikan akhlak tersebut dilihat dari perubahan tata cara pembelajaran akibat adanya covid-19 dan bertempat di SMK Negeri 1 Pedan. Metode penelitian ini adalah dengan menggunakan metode kualitatif dan tekhnik pengumpulan data melalui wawancara serta observasi lapangan dan tekhnik analisis data yang digunakan adalah model Miles and Hubberman. Tujuan penelitian ini adalah mendeskripsikan Konsep pendidikan Ibnu Miskawaih yang tampak sejalan dengan upaya pengembangan karakter bangsa Indonesia dewasa ini. Aktualisasi Pendidikan karakter menurut Ibnu Miskawaih di Indonesia dapat ditumbuh kembangkan sejak pendidikan dini, di mana peranan para pendidik (guru) atau orang tua sangat besar dalam pembinaan karakter peserta didik atau anak didiknya.
\end{abstract}

Kata Kunci: Pendidikan Karakter, Akhlak, Ibnu Miskawaih

\section{PENDAHULUAN}

Paradigma pemikiran Ibnu Miskawaih dalam bidang akhlak dapat dikatakan memiliki corak yang berbeda dengan pemikir lainnya. Hal itu dapat terlihat dalam bukunya yang berjudul Tahdzib al-Akhlak yang membahas mengenai akhlak serta banyak dikaitkan dengan pemikiran para filosof Yunani seperti Aristoteles, Plato, dan Galen. Ibnu Miskawaih juga banyak dipengaruhi oleh filosof muslim seperti al-Kindi, al-Farabi, dan al-Razi serta lainnya. Filosof Yunani dan filosof Muslim sama-sama berpendapat bahwa "Tujuan dalam suatu kehidupan adalah untuk mencapai kabahagiaan". Adapun cara memperoleh kebahagian adalah dengan beretika atau berakhlak dengan baik. Oleh karenanya banyak para ahli menggolongkan corak pemikiran Ibnu Miskawaih ke dalam tipologi etika filosofi (etika rasional), yaitu pemikiran etika yang banyak dipengaruhi oleh para filosof, terutama para filosof Yunani. ${ }^{1}$

1 Nurul Azizah, 2017, "Pendidikan Akhlak Ibnu Miskawaih Konsep dan Urgensinya dalam Pengembangan Karakter di Indonesia”, Jurnal Pendidikan Agama Islam Universitas Wahid Hasyim vol. 5 no. 2, 178.

Al Qalam: Jurnal Ilmiah Keagamaan dan Kemasyarakatan Vol. 16, No. 1

Januari - Juni 2022 
Diah Novita Fardani : Pendidikan Akhlak Masa Pandemi Covid-19 Tahun 2021 Perspektif Ibu Miskawaih (Studi Kasus di SMK Negeri 1 Pedan)

Pembinaan karakter harus dijalankan ke dalam semua lini pendidikan dan berbagai disiplin ilmu. Oleh karena itu sangat urgen jika dilakukan kajian tentang konsep akhlak Ibnu Miskawaih yang menjadi pilar pengembangan pendidikan karekter di Indonesia. Selain itu, perubahan tata laksana pembelajaran sebagai akibat dari Pandemi Covid-19 turut berdampak besar ke dalam proses internalisasi pendidikan akhlak di sekolah. SMK Negeri 1 Pedan salah satu sekolah yang turut terkena dampak perubahan konsep pendidikan akhlak tersebut. Guru PAI dan Budi Pekerti di sana saat pertama kali menghadapi perubahan akibat pandemi dituntut untuk merombak hampir semua proses pembelajaran dan evaluasi siswa dengan tetap bertujuan menanamkan nilai-nilai akhlak baik berlatar pemikiran Ibnu Miskawaih. Latar belakang di atas menjadi pertimbangan pentingnya tulisan ini dengan mengambil dua rumusan masalah, 1. Bagaimana Biografi Ibnu Miskawaih? 2. Bagaimana konsep pendidikan akhlak Ibnu Miskawaih pada masa Pandemi Covid-19 di SMK N 1 Pedan?

Konsep pendidikan akhlak Ibnu Miskawaih telah banyak dibahas sebelumnya, di antarnya: Pertama, Muliatul Maghfiroh dalam jurnalnya menjelaskan bahwa konsep pendidikan akhlak adalah dasar dari konsep pendidikan Ibnu Miskawaih. Kedekatan yang terjalin antara Miskawaih dengan para penguasa Buwaih pada masa hidupnya membawa dampak sangat besar terhadap perkembangan diri dan keilmuannya. Konsep pendidikan Ibnu Miskawaih sangat cocok diterapkan dalam konteks kekinian. Peserta didik harus dibekali dengan materi-materi yang berhubungan dengan akhlak pada setiap kegiatan pembelajaran meskipun bidang studi yang diajarkan bukan pelajaran akhlak. Jika peserta didik sudah memiliki pondasi akhlak, maka akan timbul kesadaran akan keberadaan dirinya. Maka pendidik dituntut agar bisa membimbing dan mengantarkan peserta didik ke arah yang diinginkan olehnya. ${ }^{2}$

Kedua, Najwa Mu'minah dalam tulisannya mengelaborasi antara pendidikan Imam arkasyi dan Ibnu Miskawaih. Titik tekan utama pendidikan Imam Zarkasyi dan Ibnu Miskawaih yakni tujuan pendidikan, yakni pencapaian akhlak mulia. Akhlak mulia diterjemahkan oleh Imam Zarkasyi ke dalam peringkat pertama motto pendidikan yaitu berbudi tinggi, meski basis ontologinya berbeda. Untuk menjadi insan kamil, pendidikan karakter yang menjadi tujuan pondok pesantren Gontor tercermin di dalam motto pondok pesatren. Dalam arti tujuan, seluruh proses pendidikan Pondok untuk menciptakan kader-kader umat yang memiliki empat karakter ideal: yaitu manusia berbudi tinggi (akhlaqul karimah), berbadan sehat (sehat jasmani), memiliki pengetahuan luas (broad knowledge), dan memiliki jiwa bebas. ${ }^{3}$

${ }^{2}$ Muliatul Maghfiroh, 2016, "Pendidikan Akhlak Menurut Kitab Tahzib Al-Akhlaq Karya Ibnu Miskawaih", Tadrîs Volume 11 Nomor 2 Desember 2016, 216.

${ }^{3}$ Najwa Mu'minah, 2015, "Character Building Dalam Konsep Pendidikan Imam Zarkasyi Ditinjau Dari Filsafat Moral Ibnu Miskawaih”, Jurnal Filsafat, Vol. 25, No. 1, Februari 2015, 119.

Al Qalam: Jurnal Ilmiah Keagamaan dan Kemasyarakatan Vol. 16, No. 1 Januari - Juni 2022 
Diah Novita Fardani : Pendidikan Akhlak Masa Pandemi Covid-19 Tahun 2021 Perspektif Ibu Miskawaih (Studi Kasus di SMK Negeri 1 Pedan)

Ketiga, jurnal yang ditulis oleh Nurul Azizah dengan hasil penelitian menunjukkan Ibnu Makawaih adalah filosof yang memusatkan perhatiannya terhadap akhlak. Konsep akhlaknya terpusat pada pendekatan diri terhadap tuhan dan pendekatan psikologi menjadi rujukan banyak para praktisi pendidikan. Usaha Miskawaih adalah mempertemukan ajaran syariat islam dengan teori-teori etika dalam filsafat menjadikan konsep akhlak yang digagasnya lebih komperehensif. Ada tiga hal penting atau pokok yang dapat dipahami sebagai materi pendidikan akhlaknya, yaitu: hal-hal yang wajib bagi kebutuhan tubuh manusia, hal-hal yang wajib bagi jiwa dan hal-hal yang wajib bagi hubungannya dengan sesama manusia. Ibnu Miskawaih dalam konsep karakternya menekankan aspek kejiwaan dan agama untuk meningkatkan kualitas karakter seseorang. ${ }^{4}$

Penelitian ini termasuk ke dalam jenis penelitian lapangan (field research) karena mengkaji gejala sosial yang ada di dalam pendidikan Islam. Fokus penelitian terletak pada pendidikan akhlak pada masa pandemi covid 19 tahun 2021 dalam perspektif Ibnu Miskawaih. Jenis penelitian lapangan pada hakikatnya merupakan suatu metode untuk menemukan tentang apa saja yang tengah terjadi di masyarakat. Pada prinsipnya, penelitian lapangan bertujuan untuk menggambarkan atau mendeskripsikan dan memecahkan masalah-masalah praktis dalam masyarakat, meskipun tidak semuanya. Jenis pendekatan yang digunakan dalam penelitian ini adalah pendekatan fenomenologis. ${ }^{5}$

Fenomenologi dimaknai sebagai usaha manusia untuk mengkonstruksi makna dan konsep penting dalam kerangka intersubyektivitas yang mana pemahaman tersebut dibentuk oleh interaksi manusia satu dengan manusia lainnya. Fenomenologi berasumsi bahwa orang secara aktif menginterpretasi pengalaman-pengalamannya dan mencoba memahami dunia dengan pengalaman pribadinya. Fenomenologi dapat dimaknai sebagai refleksi dari realitas yang tidak dapat berdiri sendiri karena memiliki makna yang harus ditafsirkan lebih lanjut.

\section{METODE PENELITIAN}

Penelitian ini menggunakan metode kualitatif dengan tekhnik pengumpulan data menggunakan wawancara dan observasi. Data yang terkumpul kemudian dianalisi menggunakan model Miles and Hubberman dengan cara mereduksi data, display dan memverifikasi data yang sudah diperoleh.

\section{PEMBAHASAN}

\section{A. Biodata Ibnu Miskawaih}

${ }^{4}$ Nurul Azizah, 2017, "Pendidikan Akhlak Ibnu Miskawaih Konsep dan Urgensinya dalam Pengembangan Karakter di Indonesia", Jurnal Pendidikan Agama Islam Universitas Wahid Hasyim vol. 5 no. 2, 180.

${ }^{5}$ Engkus Kuswarno, Fenomenologi: Metode Penelitian Komunikasi: Konsepsi, Pedoman, dan contoh Penelitiannya, (Bandung: Widya Padjajaran, 2009), 2.

Al Qalam: Jurnal Ilmiah Keagamaan dan Kemasyarakatan Vol. 16, No. 1

Januari - Juni 2022 
Diah Novita Fardani : Pendidikan Akhlak Masa Pandemi Covid-19 Tahun 2021 Perspektif Ibu Miskawaih (Studi Kasus di SMK Negeri 1 Pedan)

Ibnu Miskawaih adalah filosof muslim yang banyak memusatkan perhatiannya terhadap akhlak. Nama lengkap beliau adalah Abu Ali Ahmad ibnu Muhammad ibnu Yaekub ibnu Miskawaih. Ia lahir di kota Rayy, Iran pada tahun 330 H/941 M dan wafat di Kasfahan pada tanggal 09 Shafar 421 H/16 Februari 1030 M (Sirajuddin, 2014). Nama Miskawaih diambil dari kakeknya. Kakeknya semula beragama Majusi kemudian masuk Islam. Gelarnya adalah Abu Ali yang diperoleh dari nama sahabat Ali, yang bagi kaum Syie'ah dipandang sebagai seorang yang berhak menggantikan Nabi dalam kedudukannya sebagai pemimpin umat Islam setelahnya. Dengan adanya gelar ini, maka kebanyakan orang mengatakan bahwa ia adalah penganut Syiecah. Sedangkan gelar al-Khazim yang berarti bendaharawan diberikan kepadanya karena ia memperoleh kepercayaan sebagai bendaharawan di masa kepemimpinan Adid alDaulah dari Bani Buwaih. ${ }^{6}$

Ibnu Miskawaih merupakan seorang sejarawan, tabib, ilmuwan, dan sastrawan. Setelah menjelajah berbagai ilmu pengetahuan, akhirnya ia memusatkan perhatiannya pada kajian sejarah dan etika. Adapun gurunya dalam bidang sejarah adalah Abu Bakr Ahmad ibn Kamil al-Qadhi, dalam bidang filsafat adalah Ibn al-Khammar. Ia bekerja berpuluh-puluh tahun sebagai pustakawan pada sejumlah wazir dan amir Bani Buwaih, yakni: wazir Hasan al-Mahlabi di Baghdad (348-352 H), wazir Abu al-Fadhi Muhammad ibn al-Amid di Rayy (352-360 H), wazir Abu al-Fadl Ali ibn Muhammad di Rayy (360-366 H), amir Add ad-Daula ibn Buwaih di Baghdad (367-373 H) dan sejumlah amir lainnya. Riwayat pendidikan Ibnu Miskawaih tidak diketahui secara jelas, ia pun tidak menulis autobiorafi. Diduga bahwa Ibnu Misawaih tidak berbeda dengan anak pada umumnya. Ahmad Amin yangdikutip oleh Maftuhin menjelaskan bahwa pendidikan anak pada zaman Abbasiyah pada umumnya bermula dengan membaca, menulis, mempelajari al-Qur"an, dasar-dasar Bahasa Arab, tata tetib syair dan syair, dan ilmu membaca dan menulis sya ${ }^{e i r}$. Mata pelajaran tersebut diberikan di surau-surau. ${ }^{7}$

Miskawaih juga dikenali sebagai mu 'allim al-thālith atau guru ketiga selepas al-Farābī dan Aristoteles sebagai guru pertama kerana penguasaanya dalam ilmu logika dan falsafah Yunani. Beliau hidup ketika suasana intelektual yang sedang memuncak di era pemerintahan kerajaan Abbasiyyah. Ketika ini, usaha penterjemahan karya-karya asing terutama karya Yunani ke Bahasa Arab sedang giat dijalankan, ditambah lagi dengan peranan Bait al-Hikmah sebagai pusat penterjemahan dan perpustakaan untuk menyimpan khazanah ilmu. Miskawayh lebih aktif dalam bidang penulisan pada tempoh 20 tahun terakhir hayatnya berbanding awalkhidupannya. Kitab yang sangat monumental adalah Tahdhīb al-Akhlak ditulis ketika umur beliau telah mencecah 80 tahun.

\section{B. Pemikiran Ibnu Miskawaih Tentang Pendidikan Akhlak}

\footnotetext{
${ }^{6}$ Maftuhin, Filsafat Islam, (Yogyakarta: Teras, 2012), hlm. 116.

${ }^{7}$ Ibid, 117.
}

Al Qalam: Jurnal Ilmiah Keagamaan dan Kemasyarakatan Vol. 16, No. 1 Januari - Juni 2022 
Diah Novita Fardani : Pendidikan Akhlak Masa Pandemi Covid-19 Tahun 2021 Perspektif Ibu Miskawaih (Studi Kasus di SMK Negeri 1 Pedan)

Pemikiran Ibnu Miskawaih yang berkaitan dengan pendidikan akhlak dapat dilihat dari penjelasan berikut:

1. Relevansi Hakikat Manusia

Ibnu Miskawaih memandang manusia sebagai makhluk yang memiliki keistimewaan karena dalam hakikatnya manusia memiliki daya berpikir. Berdasarkan daya berpikir tersebut, manusia dapat membedakan antara yang benar dan salah, serta yang baik dan buruk. Manusia yang paling sempurna ialah mereka yang paling benar cara berpikirnya serta yang paling mulia usaha dan perbuatannya. Usaha untuk mewujudkan kebaikan merupakan indikator dari tingkat kesempurnaan dan tujuan dari pernciptaan manusia itu sendiri. ${ }^{8}$

Manusia sebagai makhluk makhluk yang memiliki keistimewaan karena memiliki daya pikir dan macam-macam daya. Menurut Ibnu Miskawaih (Helmi Hidayat, 1994), di dalam diri jiwa manusia terdapat tiga daya yaitu daya bernafsu (an-nafs al bahimiyyat) sebagai daya terendah, daya berani (an-nafs as-sabu'iyyat) sebagai daya pertengahan dan daya berpikir (an-nafs an-nathiqat) sebagai daya tertinggi. Ketiga daya ini merupakan daya manusia yang asal kejadiannya berbeda. Unsur rohani berupa bernafsu (An-Nafs AlBahimmiyyat) dan berani (an-Nafs as-Sabu'iyyat) berasal dari unsur materi sedangkan berpikir (an-Nathiqat) berasal dari ruh Tuhan karena itu Ibnu Miskawaih berpendapat bahwa kedua an-nafs yang berasal dari materi akan hancur bersama hancurnya badan dan an Nafs an-Nathiqat tidak akan mengalami kehancuran. Dalam hal ini, Ibnu Miskawaih mengatakan bahwa hubungan jiwa al-Bahimmiyyat as-Syahwiyyat (bernafsu) dan jiwa asSabu'iyyat al-Ghadabiyyat (berani) dengan jasad pada hakikatnya sama dengan hubungan saling mempengaruhi.

Ibnu Miskawaih memandang manusia sebagai khalifah Allah. Pandangan ini juga relevan dengan pandangan Permendikbud No 20 Tahun 2018 pasal 2 tentang manusia, yang di dalam tujuan tersebut disebutkan bahwa peserta didik diharapkan mampu menjadi manusia yang bertanggung jawab. Kriteria bertanggung jawab tentu erat kaitannya dengan fungsi manusia sebagai khalifah Allah. Khalifah Allah hakikatnya merupakan amanah yang diberikan kepada manusia. ${ }^{9}$

2. Relevansi Tujuan Pendidikan

8 Usman Sa'id Jalaluddin. 1994. Filsafat Pendidikan Islam: Konsep dan Perkembangan Pemikirannya. Jakarta: Raja Grafindo Persada, 135.

${ }^{9}$ Maftuhin, Filsafat Islam, (Yogyakarta: Teras, 2012), hlm. 120.

Al Qalam: Jurnal Ilmiah Keagamaan dan Kemasyarakatan Vol. 16, No. 1 Januari - Juni 2022 
Diah Novita Fardani : Pendidikan Akhlak Masa Pandemi Covid-19 Tahun 2021 Perspektif Ibu Miskawaih (Studi Kasus di SMK Negeri 1 Pedan)

Adanya relevansi konsep manusia menurut Ibnu Miskawaih dengan pandangan Permendikbud No 20 Tahun 2018 pasal 2, tentunya memiliki relevansi juga dengan tujuan pendidikan. Pertama, Ibnu Miskawaih memandang bahwa dari segi struktur kepribadiannya pendidikan bertujuan untuk terwujudnya sikap bathin yang mampu mendorong secara spontan untuk melahirkan semua perbuatan yang bernilai baik, sehingga mencapai kesempurnaan dan memperoleh kebahagiaan sejati. Kedua, Ibnu Miskawaih berpendapat bahwa dari segi peran dan fungsi manusia sebagai hamba Allah dan khalifah Allah, pendidikan bertujuan untuk mendidik manusia agar mampu menjalankan aktivitasnya dengan baik dan sempurna dengan jalan mujahadah, pengontrolan diri, persahabatan, cinta, kebaikan, dan kebahagian agar tidak ada niat untuk merusak jagad raya ini. Tujuan ini juga relevan dengan tujuan dalam Permendikbud No 20 Tahun 2018 pasal 2 yang menginginkan pendidikan melahirkan manusia yang memiliki karakter religius dan bertanggung jawab untuk menjalankan amanah khalifah Allah. Dengan demikian tampak jelas adanya relevansi pemikiran Ibnu Miskawaih tentang manusia dan tujuan pendidikan. Ibnu Miskawaih mengharapakan konsep tersebut tidak bersifat teoritis tetapi lebih kepada ranah praktis. Hal ini dibuktikan dengan konsep manusia yang bersifat menyeluruh yakni mencari kebahagiaan hidup manusia dalam artian seluas-luasnya. ${ }^{10}$

3. Relevansi Materi

Ibnu Miskawaih membagi ilmu kepada dua golongan: al-Ulumul Syarifah (ilmuilmu yang mulia) dan al-ulumul radli'ah (ilmu-ilmu yang hina). Martabat suatu ilmu sesuai dengan urutan martabat hakikat objek ilmu itu dalam alam ini, misalnya ilmu tentang manusia lebih mulia dari objek binatang, ilmu binatang lebih mulia dari tumbuh-tumbuhan. Karena itu, dapat dipahami bahwa kecenderungan Ibnu Miskawaih kepada ulumul 'aqliyah, sebagai ilmu yang utama dipelajari karena menunjang tercapainya kualitas manusia yang sempurna. Materi pendidikan akhlak yang wajib bagi kebutuhan manusia disebutkan olah Ibnu Miskawaih antara lain shalat, puasa, sa’i (Helmi Hidayat, 1994).

Ibnu Miskawaih tidak memberi penjelasan lebih lanjut terhadap contoh yang diajukan ini. Hal ini barangkali didasarkan pada perkiraanya, bahwa tanpa uraian terperinci pun orang sudah menangkap maksudnya. Gerakan-gerakan shalat secara teratur yang paling sedikit dilakukan lima kali sehari seperti mengangkat tangan, berdiri, ruku, dan sujud memang memiliki unsur olah tubuh. Shalat sebagai jenis olah tubuh akan dapat lebih dirasakan dan disadari sebagai olah tubuh (gerak badan) jika dilakukan dalam tempo yang

10 Ahmad Busroli, 2019, "Pendidikan Akhlak Ibnu Miskawaih dan Imam Al-Ghazali dalam Pendidikan Karakter di Indonesia”, Jurnal Islamic Teaching and Learning 4 (2), 245.

Al Qalam: Jurnal Ilmiah Keagamaan dan Kemasyarakatan Vol. 16, No. 1 Januari - Juni 2022 
Diah Novita Fardani : Pendidikan Akhlak Masa Pandemi Covid-19 Tahun 2021 Perspektif Ibu Miskawaih (Studi Kasus di SMK Negeri 1 Pedan)

agak lama. Konsep akhlak yang ditawarkan Ibnu Miskawaih yaitu doktrin jalan tengah sebagai dasar keutamaan akhlak, di mana yang menjadi ukuran akal dan syariat. Akal sebagai jalan tengah untuk bisa membedakan tindakan yang baik dan buruk, mana yang harus dilakukan dan yang ditinggalkan. Sedangkan agama merupakan faktor yang meluruskan karakter remaja yang membiasakan mereka untuk melakukan perbuatan baik, sekaligus mempersiapkan diri mereka untuk menerima kearifan, mengupayakan kebajikan, dan mencapai kebahagiaan melalui berpikir dan penalaran yang akurat.

Ibnu Miskawaih membagi ilmu kepada dua golongan, di Indonesia dibagi kepada dua bentuk, yaitu ilmu agama dan ilmu umum. Ilmu agama ialah ilmu yang diwahyukan artinya bersumber dari wahyu. Kategori ilmu agama ini seperti Al-Quran, qira'ah, hafalan qur'an, tafsir, sunnah, sirah nabi, sahabat, ulama, akhlak, tauhid, hadits, ushul fiqh, fiqih, bahasa Qur'an (nahwu, sorrof, dan balaghoh), metafisika Islam, perbandingan agama, dan kebudayaan Islam. Sementara ilmu umum dibagi dalam empat bagian: pertama, pengetahuan imajinatif atau seni (arsitektur Islam, bahasabahasa). Kedua, pengetahuan intelektual meliputi; pengetahuan sosial (kesusasteraan, filsafat, pendidikan, ekonomi, pengetahuan politik, pandangan Islam terhadap politik, ekonomi, kehidupan sosial, perang dan damai, dan lain-lain, kemudian, geografi, sosiologi, linguistik, psikologi, antropologi). Pengetahuan kealaman meliputi; (filsafat, sain, matematika, statistika, fisika, kimia, life sciences, astronomi, pengetahuan tentang ruang angkasa, dan lain-lain). Ketiga, rekayasa dan teknologi, kedokteran, pertanian, dan kehutanan. Keempat, pengetahuan praktis; perdagangan, administrasi, perpustakaan, home sciences, komunikasi. ${ }^{11}$

Konsep ilmu pada pendidikan Indonesia memiliki relevansi dengan pandangan Ibnu Miskawaih yaitu terciptanya manusia agar menjadi filosof. ${ }^{12}$ Oleh karena itu, pandangan Ibnu Miskawaih tentang ilmu dan klasifikasinya patut dijadikan rujukan untuk pelaksanaan pendidikan karakter di Indonesia. Penggolongan ilmu yang dilakukan oleh Ibnu Miskawaih terfokus kepada jiwa yang menjadikan sumber adanya daya berfikir oleh manusia. Sebab, ilmu yang diperoleh manusia melalui daya berfikir yang keberadaan ilmu tersebut bersumber dari kekuasaan pencipta Allah SWT. Sementara kiat untuk memperoleh keberadaan ilmu itu diserahkan kepada manusia dan bergantung pada kehendak-Nya. Perlu diketahui, untuk memperoleh kesempurnaan manusia dan segenap potensialnya perlu mengejawantahkan potensi tersebut serta berusaha untuk mempertahankannya.

\footnotetext{
${ }^{11}$ Ahmad Tafsir, 2013, Ilmu Pendidikan Islam, Bandung: PT Remaja Rosda karya Offset, 16.

12 Abuddin Nata, 2005, Pemikiran Para Tokoh Pendidikan Islam. Cet. I, Yogyakarta: Ar-Ruzz Media, 13.
}

Al Qalam: Jurnal Ilmiah Keagamaan dan Kemasyarakatan Vol. 16, No. 1 Januari - Juni 2022 
Diah Novita Fardani : Pendidikan Akhlak Masa Pandemi Covid-19 Tahun 2021 Perspektif Ibu Miskawaih (Studi Kasus di SMK Negeri 1 Pedan)

Konsep ilmu di atas sejalan dengan temuan di SMK Negeri 1 Pedan yaitu mengenai pendidikan akhlak pada era pandemi tahun 2021. Pembinaan karakter manusia selaku generasi muda dapat ditempuh dengan berbagai upaya, termasuk melalui pendidikan yang dilakukan secara terprogram, bertahap, dan berkesinambungan. ${ }^{13}$ Pendidikan karakter memiliki tujuan penanaman nilai dalam diri siswa dan pembaruan tata kehidupan bersama yang lebih menghargai kebebasan individu. Selain itu, pendidikan karakter bertujuan meningkatkan mutu penyelenggaraan dan hasil pendidikan di sekolah yang mengarah pada pencapaian pembentukan karakter dan akhlak mulia siswa secara utuh, terpadu, dan seimbang sesuai dengan standar kompetensi lulusan. ${ }^{14}$

Setelah ketetapan work from home diberlakukan, perubahan-perubahan mulai terjadi di dalam berbagai tatanan kehidupan, terlebih dalam bidang pendidikan yang mana sebelum pandemi terjadi bidang pendidikan merupakan salah satu kegiatan yang secara umum dilakukan secara tatap muka/langsung. Karena perubahan itu, maka proses pembelajaran pun menjadi berbeda. Dalam sebuah wawancara dengan guru mata pelajaran PAI dan Budi Pekerti, penulis mendapatkan beberapa informasi mengenai tata laksana pembelajaran selama daring dan pendidikan akhlak di SMK Negeri 1 Pedan.

a. Guru memberikan informasi mengenai penugasan, pelaksanaan latihan, PTS, ulangan kenaikan kelas, dan sebagainya melalui aplikasi Waatshap khususnya grup Waatshap kelas yang sudah dibuat oleh guru dan diikuti oleh seluruh siswa.

b. Mata pelajaran PAI dan Budi Pekerti sama seperti mata pelajaran lain akan dibuatkan Room khusus di aplikasi Google Classroom yang mana dalam aplikasi ini guru dapat memberikan tugas baik dalam bentuk lampiran materi, lampiran link video Youtube yang berhubungan dengan materi, lampiran materi yang dapat diakses menggunakan drive, atau sekedar melakukan presensi.

c. Selain penugasan melalui kedua media di atas, terkadang guru juga menggunakan aplikasi Zoom apabila materi yang disampaikan menuntut siswa dan guru berinteraksi secara langsung.

Walaupun proses pembelajaran dilakukan secara daring, guru tetap berusaha memaksimalkan penanaman nilai-nilai Pendidikan akhlak. Di SMK Negeri 1 Pedan sendiri ada beberapa cara yang dilakukan oleh guru PAI dan Budi Pekerti sebagai usaha dalam proses pendidikan akhlak, di antaranya:

\footnotetext{
${ }^{13}$ Hasan, Pengembangan Pendidikan Budaya dan Karakter Bangsa, (Jakarta: Litbang Puskur, 2010), 6

${ }^{14}$ Samani, Muclas, dan Hariyanto, Konsep dan Model Pendidikan Karakter, (Bandung: Remaja Rosdakarya, 2007), 42-43.
}

Al Qalam: Jurnal Ilmiah Keagamaan dan Kemasyarakatan Vol. 16, No. 1

Januari - Juni 2022 
Diah Novita Fardani : Pendidikan Akhlak Masa Pandemi Covid-19 Tahun 2021 Perspektif Ibu Miskawaih (Studi Kasus di SMK Negeri 1 Pedan)

a. Guru memberikan jurnal untuk diiisi secara jujur oleh peserta didik dengan format contoh di bawah ini:

\begin{tabular}{|c|c|c|c|}
\hline No & Hari/Tanggal & Kegiatan & $\begin{array}{l}\text { Implementasi Nilai } \\
\text { Pendidikan Akhlak }\end{array}$ \\
\hline 1 & $\begin{array}{l}\text { Senin, } 15 \text { April } \\
2021\end{array}$ & $\begin{array}{l}\text { Melaksanakan salat wajib } \\
5 \text { waktu tepat pada } \\
\text { waktunya }\end{array}$ & Religius, disiplin \\
\hline 2 & $\begin{array}{l}\text { Selasa, } 16 \text { April } \\
2021\end{array}$ & $\begin{array}{l}\text { Membantu orang tua } \\
\text { membersihkan rumah }\end{array}$ & Kerja keras dan mandiri \\
\hline 3 & $\begin{array}{l}\text { Rabu, } 17 \text { April } \\
2021\end{array}$ & $\begin{array}{l}\text { Mengerjakan tugas } \\
\text { sekolah tepat waktu }\end{array}$ & $\begin{array}{l}\text { Disiplin, mandiri, } \\
\text { menghargai prestasi. }\end{array}$ \\
\hline 4 & $\begin{array}{l}\text { Kamis, } 18 \text { April } \\
2021\end{array}$ & $\begin{array}{l}\text { Menjaga kebersihan } \\
\text { lingkungan rumah }\end{array}$ & Peduli lingkungan \\
\hline 5 & $\begin{array}{l}\text { Jumat, } 19 \text { April } \\
2021\end{array}$ & $\begin{array}{l}\text { Ketika berada di luar } \\
\text { rumah memakai masker } \\
\text { dan mengikuti protokol } \\
\text { Kesehatan }\end{array}$ & $\begin{array}{l}\text { Peduli sosial, disiplin, } \\
\text { tanggung jawab }\end{array}$ \\
\hline 6 & $\begin{array}{l}\text { Sabtu, } 20 \text { April } \\
2021\end{array}$ & $\begin{array}{l}\text { Melaksanakan ibadah } \\
\text { puasa Ramadhan }\end{array}$ & $\begin{array}{l}\text { Jujur, religius, tanggung } \\
\text { jawab }\end{array}$ \\
\hline
\end{tabular}

Table 1 jurnal harian siswa.

b. Sebagai upaya tambahan, Ketika proses pembelajaran tatap muka berlangsung, guru senantiasa memaksimalkan upaya agar peserta didik tidak hanya memahami materi dengan baik, melainkan dapat menghayati nilai-nilai positif yang juga ditanamkan di dalamnya.

Dalam proses pembelajaran, tentu akan dilaksanakan proses evaluasi/penilaian yang dilakukan dengan tujuan untuk mengukur sejauh mana pemahaman siswa terhadap materi yang disampaikan serta sebagai sarana bagi guru dalam melihat apakah nilai-nilai pendidikan akhlak yang coba ditanamkan apakah sudah diaplikasikan oleh peserta didik atau belum. Pada pembelajaran daring di SMK Negeri 1 Pedan, dalam penilaian sikap meliputi:

a. Penilaian diri

Proses penilaian diri dikakukan dengan memberikan beberapa pernyataan yang akan dijawab secara jujur oleh peserta didik, adapun rumusan pernyataan tersebut yaitu:

Al Qalam: Jurnal Ilmiah Keagamaan dan Kemasyarakatan Vol. 16, No. 1 Januari - Juni 2022 
Diah Novita Fardani : Pendidikan Akhlak Masa Pandemi Covid-19 Tahun 2021 Perspektif Ibu Miskawaih (Studi Kasus di SMK Negeri 1 Pedan)

\begin{tabular}{|c|c|c|c|c|c|c|}
\hline \multirow[t]{2}{*}{ No } & \multirow[t]{2}{*}{ Pernyataan } & \multicolumn{4}{|c|}{ Skor } & \multirow{2}{*}{$\begin{array}{l}\text { Nila } \\
\text { akhi }\end{array}$} \\
\hline & & 1 & 2 & 3 & 4 & \\
\hline 1. & $\begin{array}{l}\text { Saya tidak } \\
\text { memaksakan } \\
\text { kehendak kepada } \\
\text { orang lain }\end{array}$ & & & & & \\
\hline 2. & $\begin{array}{l}\text { Saya berlapang dada } \\
\text { dalam menerima } \\
\text { perbedaan pendapat }\end{array}$ & & & & & \\
\hline 3. & $\begin{array}{l}\text { Saya tidak mencela } \\
\text { pendirian orang lain }\end{array}$ & & & & & \\
\hline 4. & $\begin{array}{l}\text { Saya memberikan } \\
\text { kesempatan kepada } \\
\text { teman yang lain } \\
\text { agama untuk } \\
\text { melaksanakan } \\
\text { ibadahnya }\end{array}$ & & & & & \\
\hline 5. & $\begin{array}{l}\text { Saya menolong teman } \\
\text { yang sedang terkena } \\
\text { musibah }\end{array}$ & & & & & \\
\hline
\end{tabular}

Table 2 Kolom Penilaian Diri

Berdasarkan penilaian diri di atas, ada beberapa nilai karakter yang dapat ditanamkan kepada peserta didik, di antaranya yaitu:

a. Nilai karakter kejujuran, karena penilaian diri mengharuskan peserta didik menjawab secara mandiri dan sejujur mungkin.

b. Pada poin pertama, siswa diajarkan untuk menghargai pendapat orang lain dan tidak memaksakan kehendak pribadi. Nilai karakter yang ada di sini yaitu karakter toleransi, yang mana mengandung makna sebagai sikap dan tindakan yang menghargai perbedaan, baik perbedaan agama, ras, etnis, pendapat, sikap, dan lain sebagainya dengan tujuan dapat mengendalikan kehendak pribadi dan menjunjung tinggi sikap menghargai perbedaan.

c. Penilaian pribadi juga mengandung nilai karakter mandiri yang mana peserta didik dengan kemampuan dan keinginannya sendiri menjawab dengan jujur pernyataan yang telah diberikan.

d. Pernyataan tidak mencela pendapat orang lain mengandung nilai pendidikan karakter bersahabat/komunikatif yang mana peserta didik akan dapat beradaptasi dan membangun lingkungan yang bersahabat dengan orang lain di sekitarnya.

Al Qalam: Jurnal Ilmiah Keagamaan dan Kemasyarakatan Vol. 16, No. 1 Januari - Juni 2022 
Diah Novita Fardani : Pendidikan Akhlak Masa Pandemi Covid-19 Tahun 2021 Perspektif Ibu Miskawaih (Studi Kasus di SMK Negeri 1 Pedan)

e. Karakter toleransi dalam beragama juga ditunjukkan dengan tidak mengganggu atau melakukan tindakan yang merugikan pemeluk agama lain. Peserta didik akan memiliki kesadaran bahwa tiap-tiap perbedaan yang ada di sekitarnya harus dihargai dan dihormati.

f. Poin terakhir yang menunjukkan bahwa peserta didik hendaknya memiliki kesadaran untuk menolong dan membantu orang lain yang sedang mengalami musibah sebagai bentuk dari nilai karakter peduli sosial.

Tujuan utama dari penilaian diri yaitu untuk mengukur sejauh mana peserta didik dapat memahami berbagai aspek yang ada di dalam diri pribadi peserta didik. Lebih khusus, hal-hal tersebut berkaitan erat dengan nilai-nilai karakter yang berperan penting dalam kelancaran hubungan dengan orang lain.

b. Penilaian Antar Teman

Penilaian ini dilakukan oleh peserta didik dengan teman sekelasnya. Tujuan dilaksanakannya proses penilaian ini untuk mengukur sejauh mana peserta didik perduli dan memperhatikan lingkungan serta orang-orang di sekitarnya. Adapun rumusan penilaiannya yaitu:

\begin{tabular}{|c|c|c|c|c|c|c|}
\hline \multirow[t]{2}{*}{ No } & \multirow[t]{2}{*}{ Pernyataan } & \multicolumn{4}{|c|}{ Skor } & Nilai \\
\hline & & 1 & 2 & 3 & 4 & \\
\hline 1 & $\begin{array}{l}\text { Teman saya tidak memaksakan } \\
\text { kehendaknya kepada orang lain }\end{array}$ & & & & & \\
\hline 2 & $\begin{array}{l}\text { Teman saya berlapang dada dalam } \\
\text { menerima perbedaan pendapat }\end{array}$ & & & & & \\
\hline 3 & $\begin{array}{l}\text { Teman saya tidak mencela pendirian } \\
\text { orang lain }\end{array}$ & & & & & \\
\hline 4 & $\begin{array}{l}\text { Teman saya memberikan kesempatan } \\
\text { kepada teman lain yang berbeda agama } \\
\text { untuk melaksanakan ibadahnya }\end{array}$ & & & & & \\
\hline 5 & $\begin{array}{l}\text { Teman saya menolong orang lain yang } \\
\text { sedang terkena musibah }\end{array}$ & & & & & \\
\hline
\end{tabular}

Table 3 Kolom Penilaian Antar Siswa

Adapun tujuan dilaksanakannya penilaian antar teman yaitu supaya peserta didik secara jujur dan bertanggung jawab dapat melihat dan memperhatikan lingkungan di sekitarnya serta menanamkan sikap empati kepada lingkungan sekitar. Evaluasi diperlukan agar guru dapat menilai sejauh mana siswa memahami pendidikan yang diberikan. Berdasarkan pemikiran Ibnu Miskawaih

Al Qalam: Jurnal Ilmiah Keagamaan dan Kemasyarakatan Vol. 16, No. 1 Januari - Juni 2022 
Diah Novita Fardani : Pendidikan Akhlak Masa Pandemi Covid-19 Tahun 2021 Perspektif Ibu Miskawaih (Studi Kasus di SMK Negeri 1 Pedan)

maka dapat disimpulkan tujuan pendidikan akhlak adalah untuk membentuk manusia yang sempurna dengan usaha mencapai pengetahuan dan dilanjutkan dengan perbuatan.

\section{SIMPULAN}

Berdasarkan pemikiran Ibnu Miskawaih ada dua substansi dalam diri manusia, yaitu substansi material dan substansi immaterial. Manusia betul-betul akan menjadi manusia jika berperilaku sesuai dengan perilaku kekuatan berpikirnya. Kekuatan jiwa berpikir inilah yang menyebabkan manusia mengenal Tuhan. ${ }^{15}$ Karakter Islam menjadi perhatian utama para pemikir klasik Islam, atau para filosof Muslim era klasik, terutama Ibnu Miskawaih. Hal ini mengindikasikan bahwa masalah karakter menjadi bagian terpenting dalam proses pendidikan sejak dulu dan tampaknya trend pendidikan karakter kembali menjadi perhatian para pakar pendidikan bahwa pengembangan etika atau karakter tidak bisa dipisahkan dari upaya mencerdaskan kehidupan bangsa. Pendidikan akhlak yang dikembangkan pada SMK Negeri I Pedan menurut perspektif Ibnu Miskawaih digambarkan dengan penerapan nilai karakter seperti Religius, Disiplin, Kerja Keras, Mandiri, Menghargai prestasi, Peduli lingkungan, dan Bertanggung jawab. Pendidikan karakter menjadi sentral bagi pelaksanaan pendidikan, karena pendidikan karakter merupakan asas dasar bagi manusia untuk berinteraksi dengan Sang Pencipta (hablun minallah) maupun dengan sesama manusia (hablun min al-nas). Karakter seseorang bertumbuh dan terbentuk dalam kelompok, anak sejak kecilnya membutuhkan sekelompok orang yang memperhatikannya. Konsep pendidikan Ibnu Miskawaih tampak sejalan dengan upaya pengembangan karakter bangsa Indonesia dewasa ini. Aktualisasi pendidikan karakter menurut Ibnu Miskawaih di Indonesia dapat ditumbuh kembangkan sejak pendidikan dini, di mana peranan para pendidik (guru) atau orang tua sangat besar dalam pembinaan karakter peserta didik atau anak didiknya.

\section{DAFTAR PUSTAKA}

Azizah, Nurul. 2017. "Pendidikan Akhlak Ibnu Miskawaih Konsep dan Urgensinya dalam Pengembangan Karakter di Indonesia". Jurnal Pendidikan Agama Islam Universitas Wahid Hasyim vol. 5 no. 2.

Bakri, Syamsul. 2018. "Pemikiran Filsafat Manusia Ibnu Miskawaih: Telaah Kritis Atas Kitab Tahfidz Alakhlaq". Jurnal Pemikiran Islam dan Filsafat Vol. XV. No. 1.

Busroli, Ahmad. 2019. "Pendidikan Akhlak Ibnu Miskawaih dan Imam Al-Ghazali dalam Pendidikan Karakter di Indonesia”. Jurnal Islamic Teaching and Learning 4 (2).

${ }^{15}$ Syamsul Bakri, 2018, "Pemikiran Filsafat Manusia Ibnu Miskawaih: Telaah Kritis Atas Kitab Tahfidz Alakhlaq", Jurnal Pemikiran Islam dan Filsafat Vol.XV, No. 1, 163.

Al Qalam: Jurnal Ilmiah Keagamaan dan Kemasyarakatan Vol. 16, No. 1 Januari - Juni 2022 
Diah Novita Fardani : Pendidikan Akhlak Masa Pandemi Covid-19 Tahun 2021 Perspektif Ibu Miskawaih

(Studi Kasus di SMK Negeri 1 Pedan)

Hariyanto \& Fibriana Anjaryati. "Character Building: Telaah Pemikiran Ibnu Miskawaih Tentang Pendidikan Karakter”. JPII Volume 1, Nomor 1, Oktober 2016.

Hasan. 2010. Pengembangan Pendidikan Budaya dan Karakter Bangsa. Jakarta: Litbang Puskur.

Jalaluddin, Usman Sa'id. 1994. Filsafat Pendidikan Islam: Konsep dan Perkembangan Pemikirannya. Jakarta: Raja Grafindo Persada.

Kuswarno, Engkus. 2009. Fenomenologi: Metode Penelitian Komunikasi: Konsepsi, Pedoman dan contoh Penelitiannya. Bandung: Widya Padjajaran.

Maftuhin. 2012. Filsafat Islam. Yogyakarta: Teras.

Najwa Mu'minah. "Character Building Dalam Konsep Pendidikan Imam Zarkasyi Ditinjau Dari Filsafat Moral Ibnu Miskawaih”. Jurnal Filsafat. Vol. 25. No. 1. Februari 2015.

Nata, Abuddin. 2005. Pemikiran Para Tokoh Pendidikan Islam. Cet. I, Yogyakarta: Ar-Ruzz Media.

Samani, Muclas, dan Hariyanto. 2007. Konsep dan Model Pendidikan Karakter. Bandung: Remaja Rosdakarya.

Tafsir, Ahmad. 2013. Ilmu Pendidikan Islam. Bandung: PT Remaja Rosda karya Offset.

Al Qalam: Jurnal Ilmiah Keagamaan dan Kemasyarakatan Vol. 16, No. 1

Januari - Juni 2022 